ISSN 2073-4441

www.mdpi.com/journal/water

Article

\title{
Wetland Planning: Current Problems and Environmental Management Proposals at Supra-Municipal Scale (Spanish Mediterranean Coast)
}

\author{
María-Teresa Sebastiá-Frasquet *, Vicent Altur and José-Andrés Sanchis \\ Institut d'Investigació per a la Gestió Integrada de Zones Costaneres (IGIC), Universitat Politècnica \\ de València, C/Paranimf, 1, 46730 Grau de Gandia, Spain; E-Mails: vialgr@urb.upv.es (V.A.); \\ josanbla@urb.upv.es (J.-A.S.) \\ * Author to whom correspondence should be addressed; E-Mail: mtsebastia@hma.upv.es; \\ Tel.: +34-962-849-398; Fax: +34-962-849-309.
}

Received: 6 January 2014; in revised form: 4 March 2014 / Accepted: 11 March 2014 /

Published: 24 March 2014

\begin{abstract}
The policies that define the use and management of wetlands in Spain have undergone tremendous changes in recent decades. During the period of 1950-1980, Land Reform Plans promoted filling and draining of these areas for agricultural use. In 1986, with the incorporation of Spain to the European Union (EU), there was a sudden change of direction in these policies, which, thereafter, pursued restoring and protecting these ecosystems. This change, combined with increasing urban development and infrastructure pressures (e.g., roads, golf courses, etc.), creates a conflict of uses which complicates the management of these ecosystems by local governments. This study analyzes the effectiveness of policies and management tools of important coastal wetlands at the local scale in the Valencian Community (Western Mediterranean Sea) using a strengths-weaknesses-opportunities-threats (SWOT) methodology. A supra-municipal model of environmental planning is proposed to enable consistent management at a regional scale. This model enhances local government's effectiveness and it can be applied in other areas with similar problems.
\end{abstract}

Keywords: land planning; land uses; agricultural policies 


\section{Introduction}

In the current state of scientific knowledge, the great value of wetlands is undeniable, both for their functions and for the services they can provide [1]. However, even today, the management of these areas is largely influenced by social pressures regardless of their ecological value and their role in the hydrological cycle [2]. A wide range of pressures affect these ecosystems and alter the quality and quantity of water, such as: groundwater abstraction for irrigation and urban water supply, drainage of agricultural land, runoff from farming (e.g., pesticides and fertilizers), or wastewater discharge $[3,4]$.

The vast majority of recent scientific publications agree on the need for coordination between the various authorities responsible for the protection and management of these ecosystems at different levels (national, regional and local) in the context of national policies [5]. Wetland policies and management frameworks are difficult to implement and they are failing to stop the destruction of wetlands and their conversion to other land uses, in both developed and developing countries [6], especially in areas with increased competition with other land uses, such as coastal areas [2]. Local governments tend to support the realignment of boundaries to facilitate economic development when there is a conflict between conservation and infrastructure projects [7].

This problem is partially due to the rapid policy evolution in recent decades. The author of [8] describes three eras of development of the coastal wetland policy in developed countries: the era of wetland exploitation, the era of policy transition and the era of wetland conservation. There has been a major change in policy priorities in a short period of time: from drainage and conversion of wetlands for agriculture to a ban on filling and an attempt to preserve these areas for environmental purposes $[2,3,8]$. In the last decade, we have moved to a fourth era $[9,10]$. Nowadays, we aim to manage wetlands to meet a wide range of interacting environmental, social and economic objectives. According to [10], "the design of multi-objective water and wetland policies needs to build synergies between different levels of policy making and different categories of stakeholders who may be interested in different kinds of ecosystem services".

The variety of users and uses potentially conflicting and private land ownership are additional factors that hinder the implementation and effectiveness of these policies on wetlands [5,10,11]. Private land ownership is common in many countries, such as Spain [5], New Zealand [2], or China [7], although, increasingly, land is being acquired by local authorities and NGOs, as observed in the UK [3]. Both cases require the involvement of local communities in designing conservation policies and even in the management of these ecosystems. In order to avoid non-effective management tools, reference [11] recommended their simplification to a level where they can be understood and used by managers and stakeholders. In addition, the recent devolution of management responsibility to local governments with no effective changes in the balance of power in decision making causes that wetland stakeholders see the impacts of catchment development as outside their sphere of influence and hence as inevitable [11]. Local governments should care for the needs of local residents, strive to gain their support and help them to use land resources appropriately [7]. At present, the involvement of local people is rather limited and therefore conservation policies do not find their support [7]. In their analysis of national wetland policies, reference [6] pointed out that the weakest cultural connections as an impetus for wetland protection are found in the policies of countries, such as Spain, Canada, the United States, and France. 
This study applies a strengths-weaknesses-opportunities-threats (SWOT) analysis to analyze the effectiveness of local governments in the management of two important coastal wetlands of the Spanish Mediterranean coast: Pego-Oliva Wetland and La Safor Wetland (Figure 1), considering the current plans and regulations. The objective of this study is to identify the best strategy to manage these spaces effectively at local and regional level. This strategy could be applicable to other wetlands.

Figure 1. Pego-Oliva Wetland and La Safor Wetland location on the Spanish Mediterranean coast. All coastal wetlands of the Iberian Peninsula are represented.

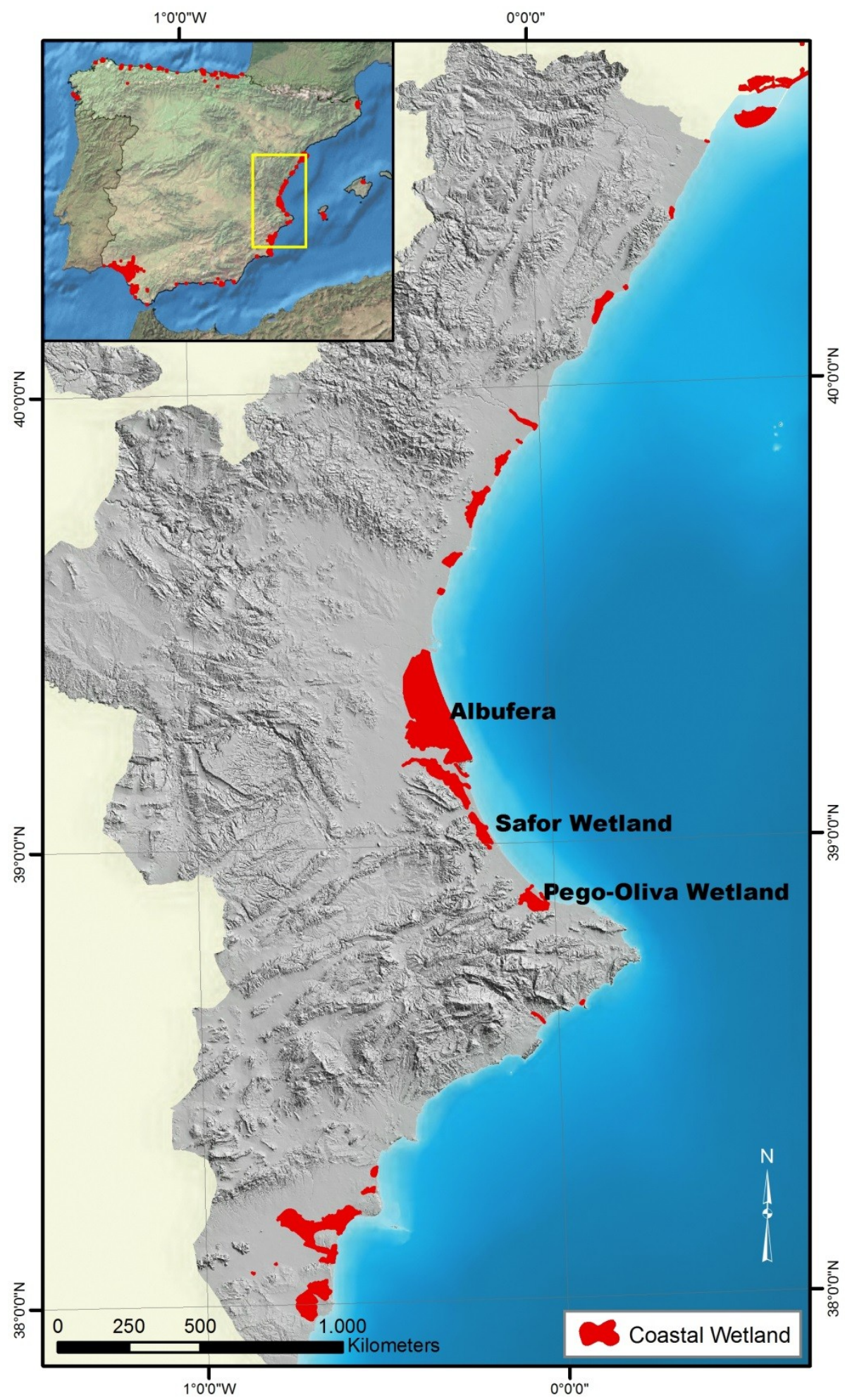




\section{Study Area: La Safor Wetland and Pego-Oliva Wetland}

Mediterranean wetlands are habitats identified for priority protection by the European Union (EU) [11]. These ecosystems are prototypes of coastal wetlands where urban and agricultural pressure compete directly with environmental water uses. La Safor Wetland and Pego-Oliva Wetland (Figure 1) are clear examples of conflict between groundwater abstraction and wetland conservation [12,13]. This conflict is common on the Mediterranean coast with similar cases in Spain, Italy, Tunisia, Morocco, Croatia, Egypt, and Greece, among others [12,13]. The high degree of human impact on these ecosystems is one of the factors hindering the implementation of plans for sustainable use and management [12]. The author of [14] grouped, into four blocks, the difficulties faced by wetlands: altered hydroperiod, impaired water quality, land use changes, and difficulty of use and management.

The selection of a local case study was governed by the consideration that it is locally where the effectiveness problems of wetlands policies are best identified [15]. In the studies of coastal wetlands on the Spanish Mediterranean coast [12], the authors pointed out the need for wetland integral management of all the policies involved: environmental, agricultural, urban planning, water, etc. Although there is a legal framework that a priori can be considered sufficient, its practical effectiveness is debatable.

The Xeresa City Council commissioned a group of experts to develop a "Special Plan" for regulating land uses in Xeresa Wetland (La Safor Wetland), to overcome daily municipal management problems. As this "Special Plan" proved to be insufficient, another strategy was needed. In this study, we compare La Safor Wetland with Pego-Oliva Wetland to analyze the effectiveness of local authorities' daily management in two coastal wetlands with similar evolution but different protection figures. This comparison allows us to: (1) analyze the effectiveness of different protection figures; (2) analyze the influence of municipal policies; and (3) determine the best strategy for wetland planning and management regardless of the particular circumstances of each ecosystem.

\subsection{Pego-Oliva Wetland}

Pego-Oliva Wetland is located in the Western Mediterranean, on the Spanish coast, on the boundary between the provinces of Valencia and Alicante (Figure 1), and belongs to two municipalities (Pego and Oliva) (Figure 2 and Table 1). In [13], there is a detailed description of the complexity of this ecosystem. This wetland is located on a coastal plain, set on a detrital aquifer, which is separated from the sea by a sand bar nine kilometers long, and has water depths of several feet deep. Groundwater upwelling creates water ponds, known as "ullals", in the wetland environment. The Bullent River and the Racons River are the wetland boundaries to the north and south, respectively. These rivers have a continuous flow regime and are fed by groundwater discharges from near karstic aquifers. This system has a total dependence on groundwater resources. These rivers are the natural drainage of the wetland to the sea, although water is also drained by pumping depending on the rice crop needs. In natural regime, estimated flow into the wetland is $54 \mathrm{hm}^{3} /$ year. 
Figure 2. Infrastructures and land uses and in the study area.
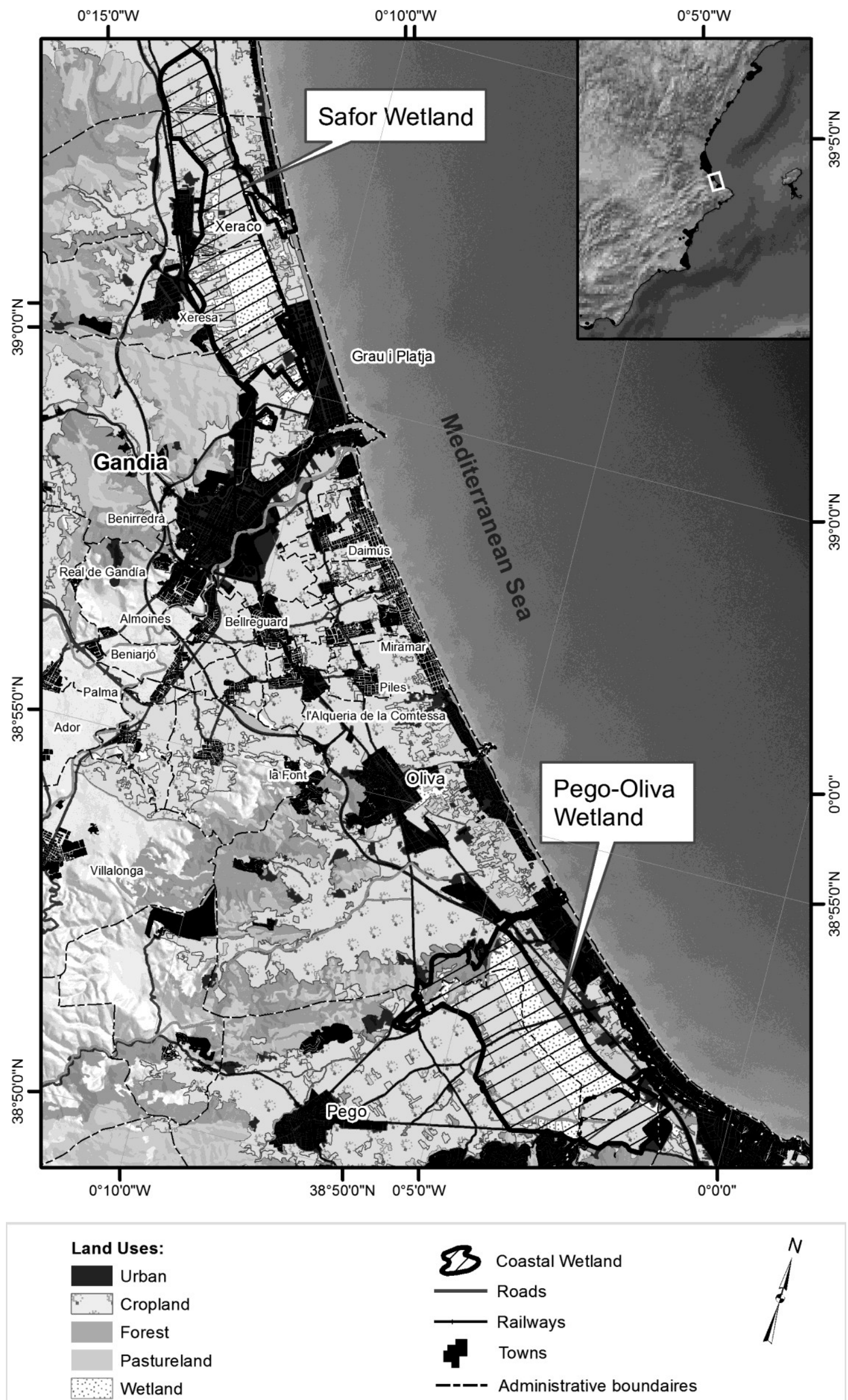

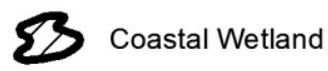

Roads

T. Towns

---- Administrative boundaires 
Table 1. Characteristics of case study towns in year of 2012. Data source: municipal records of the Valencian Institute of Statistics.

\begin{tabular}{ccccc}
\hline Town & $\begin{array}{c}\text { Number of } \\
\text { inhabitants }\end{array}$ & $\begin{array}{c}\text { Surface } \\
\mathbf{( k m}^{\mathbf{2}}\end{array}$ & $\begin{array}{c}\text { Population density } \\
\text { (inhab/.km } \mathbf{~}\end{array}$ & Coastal town \\
\hline Pego & 11,029 & 52.9 & 208.7 & No \\
Oliva & 28,207 & 59.9 & 470.7 & Yes \\
Gandía & 79,010 & 60.8 & $1,298.8$ & Yes \\
Xeresa & 2,294 & 16.9 & 136.2 & No \\
Xeraco & 6,230 & 20.2 & 308.2 & Yes \\
Tavernes de la Valldigna & 18,138 & 49.2 & 368.4 & Yes \\
\hline
\end{tabular}

\subsection{La Safor Wetland}

La Safor Wetland is located north of Pego-Oliva Wetland in Valencia (Figure 1), and belongs to four municipalities (Gandía, Xeresa, Xeraco and Tavernes de la Valldigna) (Figure 2 and Table 1). This wetland sits on La Plana Gandia-Denia detrital aquifer and is separated from the sea by a sand bar ten kilometers long. The main entrance of water comes from groundwater discharge of karst aquifers (Serra Grossa) feeding the detrital aquifer. The San Nicolás and Vaca Rivers limit the wetland area to the north and south respectively. The San Nicolás is an ephemeral watercourse; it carries great quantities of water only when torrential rain falls. The flow is only continuous in the last $1.5 \mathrm{~km}$ due to the inputs of freshwater draining La Safor Wetland and it flows into Gandia Harbour [4]. The Vaca River flows directly into the sea in the town of Xeraco; this river often floods the wetland due to storm events characteristic of the Mediterranean climate [16].

\section{Historical Evolution of Two Mediterranean Coastal Wetlands}

The difficulty of adequately managing coastal wetlands in the western Mediterranean, as in other regions, is largely determined by successive changes in management policies with respects to these ecosystems $[2,3,8]$. Thus, it is necessary to review the development of these areas to understand current problems.

\subsection{Pego-Oliva Wetland}

The authors of [12] described several representative cases of conflicts between groundwater use and conservation of coastal wetlands, including the case of Pego-Oliva Wetland. The study considered this case as a "paradigm in which conflicting interests converge", with numerous confrontations between different users in the past 40 years: since the 1970s, when the administration still had a transformationalist attitude (corresponding to the exploitation era [8]), until the last decade of the 20th century, which culminates with the declaration of Natural Park and corresponds to the conservation era [8].

The first crop in Pego-Oliva Wetland was the rice, which was introduced by the Arabs. However, its cultivation was banned in 1403 due to epidemics of malaria and cholera, and this prohibition was maintained over several centuries [17]. In 1805, rice cultivation was again authorized by Royal Order, which began to be effective in 1839 [17]. From this period dates the construction of 
various drainage ditches [12]. The expansion of rice cultivation intensified in the last two decades of the 19th century with 330 ha transformed in 1886 [13]. In 1916, an Irrigation Community was created, which is still active today [12]. In 1918, a law that promoted wetland drying and transformation due to insalubrity reasons was passed; it was named "Cambó law". Furthermore, the strong demand for rice because of international conflicts and a civil war, was the cause of the maximum expansion of this crop between 1920 and 1945, and in 1950 there were 1000 ha in operation (almost all of the wetland) [12].

In the period of 1960-1985, the profitability of rice cultivation declined and there were attempts to transform the wetland into horticultural crops. The "rice crisis" was caused by excessive production over domestic demand, excessive fragmentation of farms that prevented the introduction of mechanization measures and closure of international markets as a result of changing circumstances. The wetland was declared "Public Domain Land" in this period [18]. During the sixties, in 1967 to be precise, the economic report "Valencian Economic Promotions" proposed as possible solutions to the rice crisis the following: cooperative development, land consolidation and transformation. These measures were applied in Pego and in Tavernes de la Valldigna (La Safor Wetland). In 1970, the land consolidation project developed by the IRYDA (National Institute of Agrarian Reform and Development) was approved and it affected about $90 \%$ of the wetland surface. This transformation project raised expectations of reassessment of land prices among smallholders. Some companies began buying land on a large scale at the prospect of large projects, such as locating a Disney theme park in this area [17]. These perspectives help to explain the opposition encountered by the administration conservation measures later.

In the 1980 s, we are already in the era of transition, marked by the entry of Spain into the EU on 1 January 1986. In Europe, as reference [3] say, "the period from 1980 to 2000 marked a transition in agricultural policy from a focus on production to one that addressed growing concerns about the scale of agricultural subsidies and the environmental impacts of intensive farming." At this stage, the administration began to abandon their developmental ideas and aquifers protection, to fight against salinization problems, began to be considered a priority issue [17]. Thus, the project of land consolidation and transformation of the wetland was not carried out, and was finally halted in 1990 by decree. Frequent flooding during this period ruined most investments (large farms, fisheries, infrastructure, etc.), and were also a key factor in the abandonment of the project [17]. In this period the regional government became responsible for planning and environment [12].

In 1994, the first conservation measure was this wetland inclusion in the Ramsar Convention and declaration as Special Protection Area for Birds (SPA). In this year, it was also declared Natural Park by Law 11/1994, 27 December, with an area of 1253 ha [19]. The declaration of Natural Park met with opposition from the town of Pego, not only from the Pego City Council, but also from the local Irrigation Union, agricultural associations, landowners, and hunting and fishing associations opposed to the declaration of Natural Protected Area. Confrontation lasted more than a decade, and there was a lengthy legal process that ended with the imprisonment of the mayor of the municipality (Judgment of the Supreme Court 1073/2003). To appease the strong tensions, a range of uses and activities were allowed within the wetland, such as the growing of organic rice and vegetables, the hunting of protected birds and sport fishing. The administration purchased parcels of private land with funds from a LIFE Project granted by the EU in 1993, as a solution to conflicts with owners [17]. 
Land acquisition by authorities has been postulated as one of the solutions to improve the implementation of conservation measures [3,7].

In 1999, the Natural Resource Management Plan (NRMP) was passed by Decree 70/1999, dated 4 May 1999, of the Valencian Government [20]. This management tool was provided in the Law 11/1994. However, this NRMP was abrogated in 2004 by Decree 280/2004, dated 17 December 2004, Consell de la Generalitat, and a new document was passed. The new NRMP tried to solve the conflicts following the Natural Park declaration, as it declares in the preamble: "during the implementation of this important document, the natural area was subjected to a situation that can be described as exceptional, which, not only complicated the effective management of its natural values, but also seriously compromised the future conservation of natural resources" and "the Plan adopted in 1999 laid the foundations for establishing the improvement of various areas, always from the perspective of ensuring the survival of habitats and species in the park, but also from the standpoint of promoting the harmonious development of those human activities that had shaped that space."

In 2002, the List of wetlands of the Region of Valencia was approved, and included the Pego-Oliva Wetland Natural Park. The List determined the prohibition to change the status of the land from undeveloped to developable. This meant that expectations regarding the process of reassessment of land prices derived from speculation were not met. Moreover, without any compensation, the owners of farms and livestock were condemned to preserve existing land uses, in the best case. In addition, it was banned to crop those plots that had been abandoned prior to the List approval.

The Spanish Wetlands Inventory is regulated by Royal Decree Law 435/2004, dated 12 March 2004 [21]. Pego-Oliva Wetland (1254.994 ha) and La Safor Wetland were included in 2011 by Resolution of 9 March Dirección General de Medio Natural y Política Forestal (Spanish Official Gazette (BOE), Number 71, 24 March 2011) [22].

This ecosystem is also protected by other regulations of National level such as the Water Act [23]. Table 2 summarizes the regulations and plans in force affecting this wetland. 
Table 2. Regulations and Plans in force on the wetlands of Region of Valencia (Spain). EU: European Union; and NRMP: Natural Resource Management Plan.

\begin{tabular}{|c|c|c|c|c|}
\hline Chronology & Internacional EU & National & Regional & Local \\
\hline 1971 & Ramsar Convention. & - & - & - \\
\hline 1979 & $\begin{array}{l}\text { Council Directive } 79 / 409 / \text { EEC of } \\
2 \text { April } 1979 \text { on the conservation of } \\
\text { wild birds. }\end{array}$ & - & - & \\
\hline 1982 & - & - & - & $\begin{array}{l}\text { General Land Use Plan of } \\
\text { Oliva. }\end{array}$ \\
\hline 1983 & - & - & - & $\begin{array}{l}\text { General Land Use Plan of } \\
\text { Gandía. }\end{array}$ \\
\hline 1985 & - & - & - & $\begin{array}{l}\text { Subsidiary Rules of Planning } \\
\text { of Xeraco. }\end{array}$ \\
\hline 1986 & $\begin{array}{l}\text { Entry of Spain into the EU } \\
\text { on } 1 \text { January } 1986\end{array}$ & - & - & - \\
\hline 1989 & - & $\begin{array}{l}\text { Law } 4 / 1989 \text { for the conservation } \\
\text { of natural areas and wildlife }\end{array}$ & - & - \\
\hline 1992 & $\begin{array}{l}\text { Council Directive 92/43/EEC of } \\
21 \text { May } 1992 \text { on the conservation of natural } \\
\text { habitats and of wild fauna and flora. }\end{array}$ & - & - & - \\
\hline 1994 & $\begin{array}{l}\text { Pego-Oliva Wetland included in the } \\
\text { Ramsar Convention. }\end{array}$ & - & $\begin{array}{l}\text { Law 11/1994, } 27 \text { December of Protected } \\
\text { Natural Areas of the Region of Valencia. } \\
\text { Pego-Oliva Wetland was declared Natural Park. }\end{array}$ & - \\
\hline 1998 & - & - & - & $\begin{array}{l}\text { General Land Use Plan of } \\
\text { Xeresa; General Land Use of } \\
\text { Pego }\end{array}$ \\
\hline 1999 & - & - & $\begin{array}{l}\text { The Pego-Oliva NRMP was passed by } \\
\text { Decree } 70 / 1999 \text {, dated } 4 \text { May 1999, of the } \\
\text { Valencian Government (currently abrogated). }\end{array}$ & $\begin{array}{l}\text { The General Land Use Plan of } \\
\text { Gandia was amended according } \\
\text { to the new planning legislation. }\end{array}$ \\
\hline
\end{tabular}


Table 2. Cont.

\begin{tabular}{|c|c|c|c|c|}
\hline Chronology & Internacional EU & National & Regional & Local \\
\hline 2000 & $\begin{array}{l}\text { Directive } 2000 / 60 / \mathrm{EC} \text { of the European } \\
\text { Parliament and of the Council of } \\
23 \text { October } 2000 \text { establishing a framework for } \\
\text { Community action in the field of water policy. }\end{array}$ & - & - & $\begin{array}{l}\text { Subsidiary Rules of } \\
\text { Planning of Xeraco } \\
\text { amended according to } \\
\text { the new planning } \\
\text { legislation. }\end{array}$ \\
\hline 2001 & - & $\begin{array}{l}\text { Water Act (Royal Decree Law 1/2001, } \\
\text { dated } 20 \text { July 2001). }\end{array}$ & - & - \\
\hline 2002 & - & - & $\begin{array}{l}\text { List of wetlands of the Region } \\
\text { of Valencia }\end{array}$ & - \\
\hline 2004 & - & $\begin{array}{l}\text { Spanish Wetlands Inventory is regulated } \\
\text { by Royal Decree Law } 435 / 2004 \text {, dated } \\
12 \text { March } 2004 \text { (provided in the } \\
\text { Law 4/1989). }\end{array}$ & $\begin{array}{l}\text { Pego-Oliva NRMP passed by Decree } \\
\text { 280/2004, dated } 17 \text { December 2004, } \\
\text { Consell de la Generalitat. } \\
\text { Governing Board of the Pego-Oliva } \\
\text { Wetland Natural Park created by } \\
\text { Decree 31/2004. }\end{array}$ & $\begin{array}{l}\text { General Land Use } \\
\text { Plan of Tavernes } \\
\text { de la Valldigna. }\end{array}$ \\
\hline 2007 & - & $\begin{array}{l}\text { Law } 42 / 2007 \text { of Natural Heritage } \\
\text { and Biodiversity }\end{array}$ & - & - \\
\hline 2011 & - & $\begin{array}{l}\text { Pego-Oliva and La Safor Wetlands } \\
\text { included in the Spanish Wetlands } \\
\text { Inventory by Resolution of } 9 \text { March, } \\
\text { Dirección General de Medio Natural y } \\
\text { Política Forestal (Spanish Official } \\
\text { Gazette (BOE), Number 71, } \\
24 \text { March 2011). }\end{array}$ & - & $\begin{array}{l}\text { Special Plan of Xeresa } \\
\text { Wetland proposal. } \\
\text { Special Plan of Gandia } \\
\text { Wetland proposal. }\end{array}$ \\
\hline
\end{tabular}




\subsection{La Safor Wetland}

Land use evolution in La Safor Wetland is similar to that described for Pego-Oliva Wetland, so we will only highlight the particularities of this ecosystem. During the rice crisis, land consolidation and agricultural cooperatives were also promoted, but they were only developed in Tavernes de la Valldigna, while rice cultivation was abandoned in other municipalities. The division and ownership of the marshes in these municipalities was different. During the Spanish Civil War, large companies acquired most of the land, such as Rusticas S.A., which (currently) still owns most of the marsh. Most agricultural transformations occurred from the seventies onward. A new production system called "bancs" was introduced and the height of the plots was raised with the materials dredged from adjoining plots that became ponds. Then, vegetable and citrus crops, which could be sold at higher prices, were introduced in raised plots. Local smallholders copied the cropping system that also spread next to large farms. The land level was also raised with external contributions. Semi-confined cattle and sheep farming were also introduced. Mining licenses for peat were granted when excavating up to one and a half meters below ground level. In the 1980s and 1990s, Rusticas S.A. continued its agricultural transformation projects to create large citrus farms in Xeraco with the support of the City Council.

Development pressure was (and still is) very important due to the substantial tourism activity in Gandia Beach (Table 1). In the mid-seventies the question of the construction of the "Renaissance City" arose in the town of Xeresa; this project was originally approved by the City Council but was rejected by subsequent democratic corporations. In the eighties and nineties new development schemes related to marine leisure sports and golf emerged. In Gandia beach, housing developments spread reaching the marsh, which was already occupied by detached houses in an undeveloped area, which eventually became a residential area. In this area number of facilities including a tennis club, a shooting range, a campsite, several clubs, a university campus and a secondary education center were also built.

The 21 st century began with the first measures taken by the regional administration to halt the progressive deterioration of the ecosystem. The first protection step was the wetland inclusion in the List of wetlands of the Region of Valencia with 1226.68 ha (Table 2). By this time, almost the entire wetland was already classified as protected undevelopable land in municipal general plans (Figure 3), but city councils still had exploitation ideas and submitted various development projects linked to tourism.

In 2009, the "Mondúver-Safor Wetland SPA" was included in the new proposal of the Generalitat Valenciana (passed by Resolution of 5 June 2009, of the Consell, expansion of the network of SPA of the Region of Valencia, DOCV Number 6031, dated on 9 June 2009) [24]. In 2011, it was included in the Spanish Wetlands Inventory. In this period, the Hydrographic Confederation of Júcar, which is the authority responsible for water management, at national level, carried out various actions with the help of European Regional Development Funds (ERDF), such as the recovery of "ullals" and the purchase of surrounding land (ERDF-Natura 2000 Sites).

Since the List's approval to the present, the policy of the Regional and Local Government has been an almost total abandonment of the wetland management. The Councils of Tavernes, Xeraco, Xeresa, and Gandia have followed permissive policies to the actions of landowners, such as wetland filling for agriculture, groundwater drainage, construction of illegal buildings, and have opposed protectionist proposals of the regional administration. Action has been taken only when environmental groups have complained to the courts about filling projects developed by large farms owners. Most of these 
legal proceedings have ended with judgments favorable to the tenets of environmental groups. However, the regeneration projects required by the final judgments have not been finally executed.

Figure 3. Land classification in the study area.

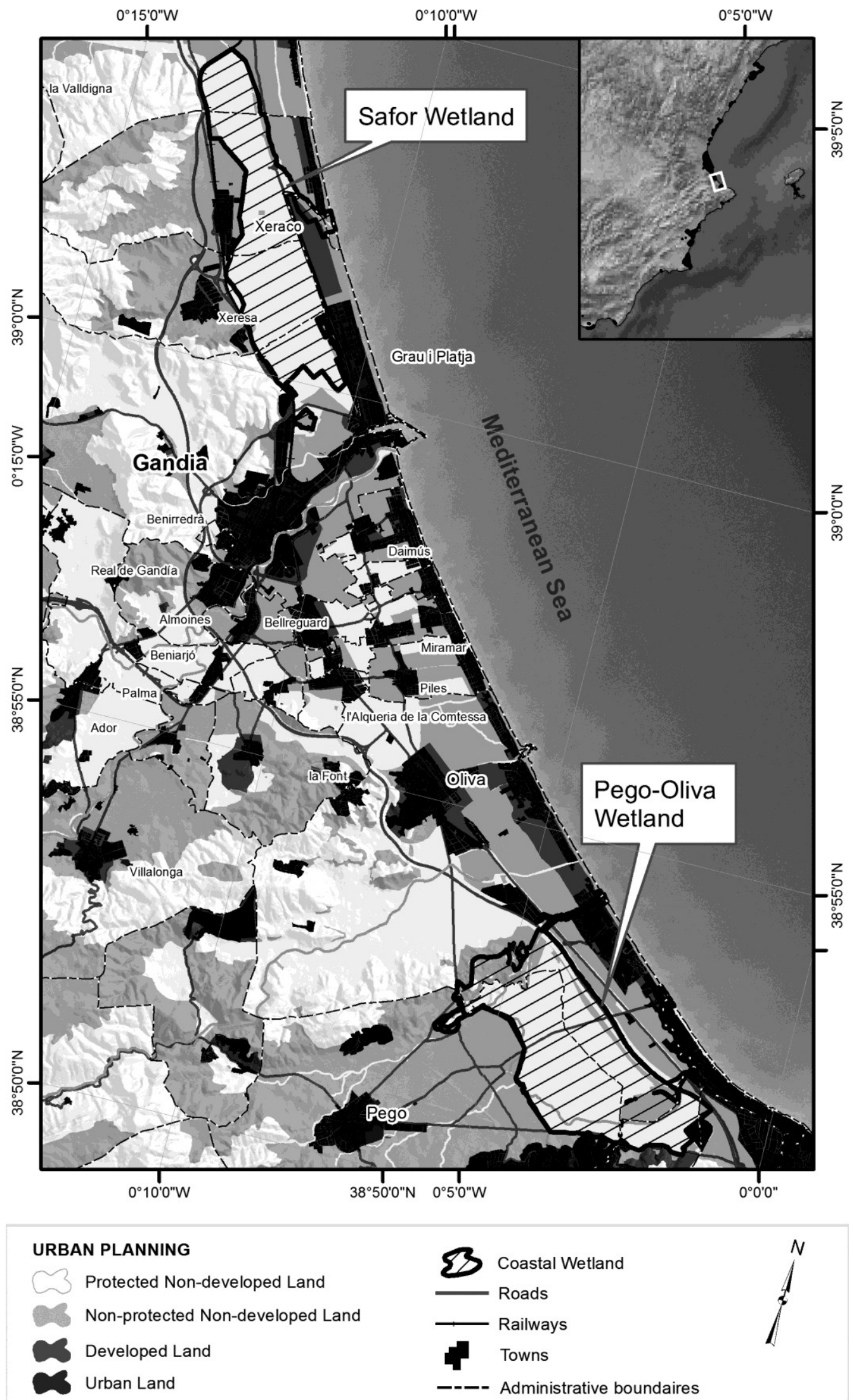




\section{Current Situation Analysis}

\subsection{Pego-Oliva Wetland}

As a consequence of all the above, nowadays we can find here the land uses represented in Figure 2, being rice, citrus crops and marsh the most important ones. The author of [25] identified 50 well surveys that pump water for crop irrigation $\left(12.7 \mathrm{hm}^{3} /\right.$ year) and urban supply $\left(3 \mathrm{hm}^{3} /\right.$ year $)$. In addition, $16.5 \mathrm{hm}^{3} /$ year are pumped to drain the citrus farm known as "La Finca del Rosario", which is near 200 ha [13], in order to decrease piezometric level and avoid root asphyxia. This causes problems of seawater intrusion in the area according to [26].

In the analysis [12], they highlight the great social opposition that originated in the second half of the 1980 s to the installation of urban water supply catchments for the neighboring municipality (Denia) with a flow rate of about $4 \mathrm{hm}^{3} /$ year. This led to the abandonment of the project, while pumping in citrus farms continued thanks to previously acquired rights.

In Pego-Oliva Wetland, pressure on communication infrastructure is very high (Figure 2). The AP-7 motorway is the artificial boundary of the park in the NO-SE direction. The CV-715 road, located in the west, joins the towns of Oliva and Pego. The CV-700 road, located in the south, joins Pego and Denia. In addition, the CV-678 road, which joins Pego with the beach, crosses the wetland. Various nearby developments located between the park and the waterfront and the proximity of resorts such as Oliva Nova Golf are an additional pressure.

This Natural Park has an administrative office whose duties are activities aimed at studying the flora, fauna, and ethnology.

\subsection{La Safor Wetland}

In Figure 2, the current status of this wetland is observed. Among the main land uses, citrus and horticultural crops stand out. In this wetland, there are at least 14 wells for urban supply (e.g., Gandia beach and Xeresa) and crop irrigation (such as Gandia's Irrigation Community) are listed. Some of the wells are operating only during the summer in the peak tourist season [4]. As in Pego-Oliva Wetland, groundwater is pumped to the sea to decrease the phreatic level and avoid citrus root asphyxia [4].

As seen in Figure 2, the wetland is subjected to the pressure of various linear structures. The Nazaret-Oliva road borders the wetland to the east, and separates the marsh and the coastal ridge. To the west, the AP-7 motorway, the N-332 national road and the Gandia-València railroad separate the alluvial valley from the Mondúver Mountain, and are located in the main groundwater upwelling area called "ullals". Currently the doubling of the railway line is projected. There is also a network of paths crossing the marsh west to east, parallel to each other. These paths are used to communicate towns and beaches. Currently, the City Council of Gandia is pressing to create a new road connecting the exit of the AP-7 motorway with Nazaret-Oliva road for a direct access to Gandia Beach, which is a major tourist destination [4]. Overhead power lines also cross this wetland.

Unlike Pego-Oliva Wetland, the Safor Wetland has no management document approved, so it is governed by the multiplicity of regulations and plans detailed in Table 2 . The different councils are the mediators between residents and owners and the responsible authorities. However, they cannot issue 
licenses or perform maintenance of this space, so any petition filed before the City Council must be dealt with the competent administration and expect permission.

As we have mentioned before, the Xeresa City Council, in an attempt to overcome the daily difficulties found in the local management of this area, developed and initially approved a "Special Plan" in 2011. This Plan established zoning and regulation for each zone. At present this proposal has not yet been approved by the Regional Government. At the same time, the City of Gandia prepared a Special Plan, but with a completely different purpose: reordering uses to allow the construction of a mini golf course on protected undeveloped land in the wetland. The Special Plan, as a tool for urban planning, could be a useful instrument to improve the effectiveness of local authorities. However, it has been revealed inadequate for two main reasons: (1) limited scope; and (2) diversity of purposes depending on the interests of the local authority.

\section{SWOT Analysis}

\subsection{SWOT Methodology}

SWOT analysis is a leading tool for strategic analysis [27]. This tool was designed to be used in the preliminary stages of decision-making and as a precursor to strategic management planning [28]. SWOT analysis has been successfully used in planning processes related to local and regional development [29]. The authors of [30] applied this methodology for river basin management, and they emphasized that public participation and stakeholders' involvement are key elements for its successful implementation due to the special cultural and social attitudes toward water.

There are many variations on the basic SWOT analysis [31]. In this study, we followed the next steps:

Step 1. Define the objective of the SWOT analysis

The SWOT analysis aims to identify the best strategy to effectively manage coastal wetlands at local and regional level.

Step 2. Initial diagnosis of current plans and regulations

We analyzed the effectiveness of different protection figures and the influence of municipal policies. A comparison was made between two representative coastal wetlands: La Safor Wetland and Pego-Oliva Wetland. Knowledge of the evolution experienced by these coastal wetlands, which has led to the current situation, is essential to make a good analysis. This evolution has been described in detail for local case studies; however, it is also representative of the conflicts experienced in other coastal areas, located on the Mediterranean Sea [13] and in different geographical regions [7,8,15].

Step 3. Stakeholder analysis

This analysis is the first step to involve local actors in the planning/management process; it reduces the risk of neglecting an important actor and gives us an idea of the different perspectives from which the problem is viewed [30].

At an initial stage, the stakeholder analysis was developed for the representative case of Xeresa town, and later it was applied to the rest of study cases. Most wetland conservation issues can be observed in this municipality. This is a non-coastal town with a low population density (Table 1) and 
few development opportunities, as it is protected by the Mondúver-Safor Wetland Site of Community Importance (SCI). Most of the marsh plots are privately owned and are, on average, quite small. This municipality does not benefit from coastal tourism but suffers its pressure (e.g., demand of a road that links it to Gandia Beach).

The processes of public participation implemented in the Special Plan of Xeresa's Wetland and Agenda 21 served as a basis for the stakeholder analysis. The main groups identified were: owners, farmers, irrigators, hunters, fishermen, residents, conservationists, and companies.

Step 4. Diagnosis configuration in SWOT matrix

This step involved experts, members of the local administration and stakeholders representatives. In the SWOT matrix, strengths and weaknesses are seen as internal factors, which can be acted upon. Thus, in this analysis, we considered as internal factors those that can be controlled by the local authority and the municipality. Opportunities and threats are external, uncontrollable factors, which form the external environment within which the organization operates [31]. In this analysis, these are those factors depending on a supra-municipal organism or affecting a vaster territory.

\section{Step 5. Selection of strategies}

Assessment and selections of strategies was accomplished by experts. According to [31], a primary misuse of the SWOT tool is the failure to link SWOT results to any subsequent strategic planning application. However, in this study the objective is to apply the results of SWOT analysis to local planning and management.

\subsection{SWOT Analysis Results}

The matrix with the SWOT diagnosis is presented in Table 3.

The results of the SWOT analysis are discussed taking into account the practical recommendations of the Ramsar Secretariat for stakeholders to respond to the value of water and wetlands in decision making [10].

The most important strength of local authorities in managing wetlands is the proximity to the territory, which allows first-hand knowledge of the issues affecting these ecosystems (e.g., the interactions between wetland ecosystems, communities, man-made infrastructures, and the economy in the area). This knowledge should be shared with decision makers [10]. Water and wetlands provide a wide range of values and benefits to society [9]; however, disseminating knowledge of these benefits to local communities is essential because these are often either not recognized, or only one is appreciated [10].

An effective and efficient regulation of activities that impact water and wetlands is also necessary [10]. Local authorities can improve regulation and land use planning because they hold the competencies for zoning regulations in municipalities. Special Plans are local planning tools that regulate uses and activities. However, as we have seen before, these plans present several disadvantages (e.g., limited scope, diversity of purposes and need to be approved by the Regional authorities). In addition, Special Plans are limited to local scale, thus, they do not solve problems affecting the wetlands because these ecosystems have a wider influence area (aquifers and watersheds). 
Table 3. Strengths-weaknesses-opportunities-threats (SWOT) matrix.

\begin{tabular}{|c|c|c|}
\hline \multirow[b]{2}{*}{$\begin{array}{l}\text { Internal environment } \\
\text { (factors which can be } \\
\text { controlled by the local } \\
\text { authority and } \\
\text { the municipality) }\end{array}$} & Stre & Weaknesses \\
\hline & $\begin{array}{l}\text { - } \quad \text { Proximity to the territory; } \\
\text { - } \quad \text { Knowledge of its territory; } \\
\text { - } \quad \text { Comprehensive knowledge of wetlands } \\
\text { and its issues; } \\
\text { - } \quad \text { Knowledge dissemination; } \\
\text { - } \quad \text { Regulation and land use planning. }\end{array}$ & $\begin{array}{l}\text { - Private property of land; } \\
\text { - } \text { Stakeholders not involved; } \\
\text { - } \text { Conflicts of interest } \\
\text { among stakeholders; } \\
\text { - } \text { Differential management according to } \\
\text { the political orientation of } \\
\text { the administration; } \\
\text { - Poor definition of prohibited, permitted } \\
\text { and conditional uses and activities; } \\
\text { - } \text { Demand for developable land. }\end{array}$ \\
\hline \multirow[b]{2}{*}{$\begin{array}{l}\text { External environment } \\
\text { (factors depending } \\
\text { on a supra-municipal } \\
\text { organism or affecting } \\
\text { a vaster territory) }\end{array}$} & Opportunities & Threats \\
\hline & $\begin{array}{l}\text { - Policy and management frameworks } \\
\text { agree on the need for wetland conservation } \\
\text { and the creation of new management tools; } \\
\text { - Coordination of responsible authorities; } \\
\text { - Involve users in the management process } \\
\text { and take their needs into account; } \\
\text { - } \quad \text { Balancing all ecosystem services; } \\
\text { - Integral management of the influence area; } \\
\text { - } \quad \text { Land purchase by the administration; } \\
\text { - Compensation mechanisms. }\end{array}$ & $\begin{array}{l}\text { Responsibilities divided into all levels } \\
\text { of government: lack of coordination; } \\
\text { - Demand for developable land and } \\
\text { infrastructure pressure; } \\
\text { - Wide influence area (watersheds } \\
\text { and aquifers); } \\
\text { - } \quad \text { Loss of environmental values } \\
\text { and services; } \\
\text { - } \quad \text { Funding. }\end{array}$ \\
\hline
\end{tabular}

The main identified weaknesses here are common to other coastal wetlands, although some are particularly relevant in the study area. There is widespread consensus that private land ownership complicates management of protected areas and limits the scope of action of the various administrations. In some countries, the protection of wetlands on private land has been identified as a national priority. It is the case of New Zealand, where over $75 \%$ of small wetlands (smaller than 10 ha) are on private land [2]. In the case studies described, private property accounts for more than $90 \%$ of the land (90.1\% in the case of Pego-Oliva Wetland and $91.9 \%$ for La Safor Wetland). One solution to this increasing problem is the purchase of land by the administration [3]. However, the associated cost can make this alternative impractical in the case of small towns like those involved in this study, where the land purchases were made possible thanks to the help of European Funds. In this situation it is particularly important to involve the owners and users in decision-making and in the daily management of the protected area.

Local authorities usually need to mediate when conflicting interests among different users arise. Conflicting demands for water and land are continuous and inevitable, and usually are in conflict with wetland conservation (e.g., infrastructure pressure and developable land demand) [8,32]. Recognizing and strengthening the link of local communities to wetlands is critical in transforming the management approach [10]. In addition, depending on the political orientation of the administration, these conflicts can be solved with different purposes and usually governments take decisions having into account the political repercussions at the polls. Corruption can be a major impediment to maintain the integrity of these ecosystems [10]. 
The poor definition of prohibited, permitted and conditional uses and activities creates insecurity among users, through ignorance of the applicable regulations and fear of sanctions. In this context, farmers abandon some practices, which sometimes play an important role in wetland conservation. In fact, the role of traditional practices has not only been recognized, but also has been recommended to consider them in wetland management [10]. To avoid this undesired situation, environmental regulation should focus on three approaches [10]: regulation of water (discharges, management practices, limits of abstraction, etc.), regulation of products (product use and production standards), and spatial planning (which regulates land uses).

The main threat to the management of local authorities is the division of administrative competences in coastal wetlands of Spain. Environment responsibilities were transferred to the regional authorities (Autonomous Communities), but Water and Coast are responsibility of National authorities [33]. To this must be added the multiplicity of existing environmental figures.

Groundwater abstraction for various purposes (irrigation, drainage of farmland and urban supply) poses a threat to the quality and quantity of water resources essential to the survival of these ecosystems. Despite the different types of protection, these abstractions continue. Even in cases as serious as that of Tablas de Daimiel National Park, national and regional authorities did not dare to enforce restrictive measures, which were unpopular among groundwater users [5,34]. Almost all the factors that may affect wetlands occur outside the limits of the wetland itself (e.g., groundwater abstraction for urban supply, fertilizers and pesticides runoff, etc.). In the study area, the definition of a $500 \mathrm{~m}$ buffer area around the wetland was an arbitrary choice (Wetland List) that did not follow any scientific criteria. For instance, there is an industrial park located in Xeresa, outside the buffer area limits but into the catchment area of the Safor Wetland. Thus, industrial discharges flow directly into the wetland. To avoid these problems the ecosystem approach should be undertaken at the appropriate spatial and temporal scales. Thus, proper management boundaries must be defined by users, managers, scientist and local people and should consider the influence area (watersheds and aquifers) [5].

Protection of wetlands does not usually bring economic benefits to many people, but can negatively impact other stakeholders [10]. Social fairness should be included as an objective of ecosystem management. Compensation measures may be necessary to recognize ecosystem service providers, especially those whose interests are more severely affected.

To solve the effectiveness of local authorities in daily management, new supra-municipal level tools that incorporate the rest of opportunities identified in the analysis should be developed. Thus, it should serve to coordinate the responsible authorities, aim to an integral management of the influence area and involve users in the management taking into account their needs. Local experts and stakeholders can provide insights into the dynamics of the system and help assessing the feasibility and acceptance of proposed management measures [11].

\section{Proposed Strategy}

The Spanish environmental regulation has been criticized because it is more indirect than practical and lacks environmental performance [6]. In addition, cultural connections as an impetus for wetland protection are very weak. The proposed strategy aims to overcome these deficiencies, taking into account the SWOT analysis results. 
A practical tool for planning and management of supra-municipal level should be developed. This tool should establish wetland zoning having into account bio-physical, socio-economic and institutional characteristics, land uses and planning classification, and general and specific regulations for each zone, including the definition of prohibited, permitted and conditional uses and activities. Prohibited uses may be permanent or temporary. Permitted uses must be clearly specified to avoid regulatory gaps that may cause undesirable conflicts. This tool should also define which organism or organisms will be responsible for approval of conditional uses and establish its concession procedures.

Stakeholders should be integrated in the active management of these areas and the division of competences among different level authorities should be harmonized. Thus, we should aim to the creation of a joint management organism of the various administrations involved, able to coordinate the disparity of competences. To ensure the representativeness and effectiveness of this organism, various levels of organization should be established to act in accordance with the importance, severity or urgency of the issues addressed and these decisions would take precedence over those of any of the other administrations represented. This organism will be managed by the administration with responsibilities in environment. This organism should include a surveillance section to ensure the accomplishment of plans and regulations.

In the next two tables there is an example of organization for wetlands management: in Table 4, we include proposed planning tools; and in Table 5 the composition and functions of proposed management organisms. This proposal seeks to overcome the main weaknesses and threats identified in the SWOT analysis that difficult local government effectiveness in daily wetland management.

Table 4. Proposed planning tools.

\begin{tabular}{|c|c|c|}
\hline Regional Action Plan & Special Plans of Conservation & Public Consultation Forum \\
\hline 1. Informative report and plans & $\begin{array}{l}\text { 1. Informative and supporting report and } \\
\text { supplementary studies }\end{array}$ & 1. General assembly \\
\hline $\begin{array}{l}\text { 2. Binding part: } \\
\text { a. Objectives; } \\
\text { b. Strategies; } \\
\text { c. Planning; } \\
\text { d. Regulations. }\end{array}$ & $\begin{array}{l}\text { 2. Documentation with } \\
\text { regulatory effectiveness: } \\
\text { a. Planning plans; } \\
\text { b. Protection rules. }\end{array}$ & 2. Chairperson \\
\hline 3. Environmental assessment & 3. Infrastructure and building rules & 3. Secretary \\
\hline- & - & 4. Experts \\
\hline
\end{tabular}


Table 5. Proposed management organisms: composition and functions.

\section{Joint Management Organism \\ Composition:}

1. Chairperson: named by the environmental administration.

2. Representatives of the authorities responsible for the following areas:

i. Agriculture;

ii. Water;

iii. Land planning;

iv. Environment;

v. Coasts;

vi. Infrastructures.

3. Representatives of the municipalities affected by the wetland.

4. Representatives of the social agents of the following areas:

i. Farmers;

ii. Irrigators;

iii. Hunters;

iv. Fishermen;

v. Conservationists;

vi. Residents;

vii. Companies.

5. Technical staff and representatives of academic institutions:

i. Environmental agents;

ii. Technical staff;

iii. Scientific researchers;

iv. Experts.

\section{Functions:}

1. Approval and revision of planning and management instruments.

2. Approval of plans and projects in the wetland.

3. Inform on plans and projects by other agencies that may affect the wetland.

4. Approval of the annual budget and the annual report of activities.

5. Approve the delegation of responsibilities to other management organisms.

6. Prepare the internal regulations of the other management organisms.

\section{Intermediate Management Organisms}

Standing Management Committee

\section{Composition:}

1. Chairperson.

2. Council Representatives.

3. Technical staff.

4. Environmental agents.

\section{Functions:}

1. Resolve permission application for specific uses and activities.

2. Resolve permission application for conservation and improvement works.

3. Coordinate municipal plans and projects with an impact on the wetland.

4. Resolve specific conflicts between owners and/or administrations.

5. Determine which provisions have to be raised to the joint management organism.

6. Establish the indications for direct action at the technical office of the area.

\section{Technical Office}

\section{Composition:}

1. Technical staff.

2. Environmental agents.

3. Contributors.

\section{Functions:}

1. Surveillance and control of uses and activities.

2. Register of permission applications for uses, activities, works and improvements.

3. Reporting on permission applications and detected infractions.

4. Preparation of reports required by the rest of management organisms.

5. Tracking and control of plans and projects carried out in the area.

6. Inform the owners and visitors.

7. Maintenance of wetland internal signposting.

8. Environmental education tasks. 


\section{Conclusions}

We have analyzed the effectiveness of local authorities' daily management in two coastal wetlands with different protection figures. Neither the NRMP nor the Special Plan tools proved effective. The transition to the ecosystem management approach needs a more integrated decision-making approach. In this process, engagement with local people is critical.

We have elaborated a proposal to overcome the main problems common to wetlands management. The development of new supra-municipal tools is needed (Regional Action Plan, Special Plans of Conservation, and Public Consultation Forum). Moreover, a joint management organism of the various administrations involved will be able to coordinate the responsible authorities, develop an integral management of the influence area and involve stakeholders in the active management of these areas. The participation of local people, both in the Public Consultation Forum (General Assembly) and in the joint management organism, is a key factor to get them involved in management decisions. In addition, knowledge dissemination activities can help people understand the values and benefits they obtain from water and wetlands. However, to ensure effective community engagement in management solutions, the winners-losers approach should be abandoned. Policy makers and site managers, when possible, should use economic instruments to rationalize ecosystem services.

\section{Acknowledgments}

We acknowledge the Xeresa City Council for their participation in this study.

\section{Conflicts of Interest}

The authors declare no conflict of interest.

\section{References}

1. Maltby, E. The Changing Wetland Paradigm. In The Wetland Handbook; Maltby, E., Barker, T., Eds.; Wiley-Blackwell: Oxford, UK, 2009; pp. 3-42.

2. Myers, S.C.; Clarkson, B.R.; Reeves, P.N.; Clarkson, B.D. Wetland management in New Zealand: Are current approaches and policies sustaining wetland ecosystems in agricultural landscapes? Ecol. Eng. 2013, 56, 107-120.

3. Maltby, E.; Acreman, M.; Blackwell, M.S.A.; Everard, M.; Morris, J. The challenges and implications of linking wetland science to policy in agricultural landscapes-Experience from the UK National Ecosystem Assessment. Ecol. Eng. 2013, 56, 121-133.

4. Sebastiá, M.T.; Rodilla, M.; Sanchis, J.A.; Altur, V.; Gadea, I.; Falco, S. Influence of nutrient inputs from a wetland dominated by agriculture on the phytoplankton community in a shallow harbour at the Spanish Mediterranean coast. Agric. Ecosyst. Environ. 2012, 152, 10-20.

5. Amezaga, J.M.; Santamaria, L. Wetland connectedness and policy fragmentation: Steps toward a sustainable European wetland policy. Phys. Chem. Earth Part B Hydrol. Ocean. Atmos. 2000, 25, 635-640.

6. Durigon, D.; Hickey, G.M.; Kosoy, N. Assessing national wetland policies' portrayal of wetlands: Public resources or private goods? Ocean Coast. Manag. 2012, 58, 36-46. 
7. Xie, Z.; Xu, L.; Duan, X.; Xu, X. Analysis of boundary adjustments and land use policy change-A case study of Tianjin Palaeocoast and Wetland National Natural Reserve, China. Ocean Coast. Manag. 2012, 56, 56-63.

8. Kim, S.G. The evolution of coastal wetland policy in developed countries and Korea. Ocean Coast. Manag. 2010, 53, 562-569.

9. Millennium Ecosystem Assessment. Ecosystems and Human Well-Being: Wetlands and Water Synthesis; World Resources Institute: Washington, DC, USA, 2005.

10. Russi, D.; ten Brink, P.; Farmer, A.; Badura, T.; Coates, D.; Förster, J.; Kumar, R.; Davidson, N. The Economics of Ecosystems and Biodiversity for Water and Wetlands; Institute for European Environmental Policy (IEEP): London, UK; Brussels, Belgium; and Ramsar Secretariat: Gland, Switzerland, 2013.

11. Cools, J.; Johnston, R.; Hattermann, F.F.; Douven, W.; Zsuffa, I. Tools for wetland management: Lessons learnt from a comparative assessment. Environ. Sci. Policy 2013, 34, 138-145.

12. Fornés, J.M.; de la Hera, A.; Ballesteros, B.; Aragón, R. Conflicts between groundwater development and wetland conservation in the Spanish Mediterranean area. Bol. Geol. Min. 2008, 119, 231-246.

13. Ballesteros, B.J.; Domínguez, J.A.; Díaz-Losada, E.; García, O. Mediterranean wetland and associated aquifers. Hidrogeology of Pego-Oliva Natural Park (Alicante-Valencia, Spain). Bol. Geol. Min. 2009, 120, 459-478.

14. Camacho, A. La gestión de los humedales en la política de aguas en España. In Panel Científico-Técnico de Seguimiento de la Política de Aguas; Fundación Nueva Cultura del Agua: Zaragoza, Spain, 2008; p. 36 (in Spainish). Available online: http://www.unizar.es/fnca/varios/ pane1/14.pdf (accessed on 20 February 2012).

15. Fletcher, S.; Kawabe, M.; Rewhorn, S. Wetland conservation and sustainable coastal governance in Japan and England. Mar. Pollut. Bull. 2011, 62, 956-962.

16. Sebastiá, M.T.; Rodilla, M.; Falco, S.; Sanchis, J.A. Analysis of the effects of wet and dry seasons on a Mediterranean river basin: Consequences for coastal waters and its quality management. Ocean Coast. Manag. 2013, 78, 45-55.

17. Urios, V. The Administration and the wetland management problems: The Oliva-Pego Marsh (Valencia). Bol. SEHUMED 1997, 2, 1-2.

18. Decree Law 1068/1970, Dated 21 March, Number 89; Spanish Official Gazette (BOE): Madrid, Spain, 14 April 1970.

19. Law 11/1994, Dated 27 December, Number 33; Spanish Official Gazette (BOE): Madrid, Spain, 8 February 1995.

20. Decree 70/1999, Dated 4 May 1999, of the Valencian Government, Number 3490; Valencian Official Gazette (DOGV): Valencia, Spain, 7 May 1999.

21. Royal Decree Law 435/2004, Dated 12 March 2004, Number 73; Spanish Official Gazette (BOE): Madrid, Spain, 25 March 2004.

22. Resolution of 9 March Dirección General de Medio Natural y Politica Forestal, Number 71; Spanish Official Gazette (BOE): Madrid, Spain, 24 March 2011 (in Spanish).

23. Royal Decree Law 1/2001, Dated 20 July 2001, Number 176; Spanish Official Gazette (BOE): Madrid, Spain, 24 July 2001. 
24. Resolution of 5 June 2009, of the Consell, Expansion of the Network of SPA of the Region of Valencia, Number 6031; Valencian Spanish Gazette (DOCV): Valencia, Spain, 9 June 2009.

25. Obartí, J. Plan de protección hídrica del Parque Natural del Marjal de Pego-Oliva. In Conflictos en el Desarrollo de Las Aguas Subterráneas y la Conservación de Los Humedales: Litoral Mediterráneo; Fornés, J.M., Llamas, M.R., Eds.; Fundación Marcelino Botín \& Ediciones Mundi-Prensa: Madrid, Spain, 2003; pp. 127-158 (in Spanish).

26. Ballesteros, B.J.; López, J.C.; Martos, S. Tipología y características hidrogeológicas de las planas litorales del levante español. In Proceedings of the VIII Simposio de Hidrogeología: Zaragoza, Spain, 18-22 October 2004; pp. 235-249 (in Spanish).

27. Coman, A.; Ronen, B. Focused SWOT: Diagnosing critical strengths and weaknesses. Int. J. Prod. Res. 2009, 47, 5677-5689.

28. Johnson, G.; Scholes, K.; Sexty, R.W. Exploring Strategic Management; Prentice-Hall Canada: Scarborough, ON, Canada, 1989; p. 345.

29. Terrados, J.; Almonacid, G.; Pérez-Higueras, P. Proposal for a combined methodology for renewable energy planning. Application to a Spanish region. Renew. Sustain. Energy Rev. 2009, 13, 2022-2030.

30. Mylopoulos, Y.; Kolokytha, E.; Kampragou, E.; Vagiona, D. A combined methodology for transboundary river basin management in Europe. Application in the Nestos-Mesta catchment area. Water Resour. Manag. 2008, 22, 1101-1112.

31. Chermack, T.J.; Kasshanna, B. The use and misuse of SWOT analysis and implications for HRD professionals. Hum. Resour. Dev. Int. 2007, 10, 383-399.

32. Wattage, P.; Mardle, S. Stakeholder preferences towards conservation versus development for a wetland in Sri Lanka. J. Environ. Manag. 2005, 77, 122-132.

33. Serrano, D. Los humedales Ramsar en España: Reflexiones a propósito de su trigésimo aniversario. Investig. Geográficas 2012, 57, 129-148 (in Spanish).

34. Fornés, J.; Rodriguez, J.A.; Hernández, N.; Llamas, M.R. Possible Solutions to Avoid Conflicts Between Water Resources Development and Wetland Conservation in the "La Mancha Húmeda" Biosphere Reserve (Spain). Phys. Chem. Earth Part B Hydrol. Ocean. Atmos. 2000, 25, 623-627.

(C) 2014 by the authors; licensee MDPI, Basel, Switzerland. This article is an open access article distributed under the terms and conditions of the Creative Commons Attribution license (http://creativecommons.org/licenses/by/3.0/). 